\title{
STUDENTS' WILLINGNESS TO COMMUNICATE USING ENGLISH: A SURVEY STUDY
}

\author{
Ajeng Ayu Rihardini ${ }^{1}$, Rahmati Putri Yaniafari ${ }^{2}$, Nur Mukminatien ${ }^{3}$ \\ ${ }^{1}$ Universitas Negeri Malang, ajeng.ayu.1602216@students.um.ac.id \\ ${ }^{2}$ Universitas Negeri Malang, yaniafari.fs@um.ac.id \\ ${ }^{3}$ Universitas Negeri Malang, nur.mukminatien.fs@um.ac.id
}

\begin{abstract}
In Indonesia, one of the common problems encountered by many English teachers during the process of teaching and learning in the classroom is students' unwillingness to communicate in English. Having learners who are willing to communicate in English is essential in a language classroom that follows communicative approach (Riasati, 2012). This study aims to investigate students' perceptions towards willingness to communicate using English during classroom interaction. It employs a quantitative approach, survey research design. To know the students' willingness to communicate using English, a well-known FLCAS (Foreign Language Classroom Anxiety Scale) developed by Horwitz, E.K., Horwitz, and M. B., Cope J. (1986) was adapted. 115 students of SMK Negeri 10 Malang participated as the respondents. Based on the findings, it is concluded that tenth and eleventh grade students at SMK Negeri 10 Malang have a positive opinion towards willingness to communicate using English in the classroom. They said that learning and communicating using English is essential and beneficial. However, their willingness to communicate using English itself is quite low and this poses a serious problem.
\end{abstract}

Keywords: Speaking; Foreign Language Anxiety; Willingness to Communicate

\section{INTRODUCTION}

Riasati (2012) states that it is essential in a language classroom with communicative approach to have learners who are willing to communicate using English. However, in Indonesia, this seems to be a problem since many English teachers often have to face students' unwillingness to use English. Research shows that lack of using the language caused an ineffective interaction and language production. The Cambridge International Dictionary of English defines the word 'to interact' as to communicate with or react to (each other). Brown (2001) links interaction to communications, saying, “... interaction is, in fact, the heart of communication: it is what communication is all about." Here, interaction and communication mean students' participation in the classroom. Classroom interaction is related to language learning, and communicating using L2 is considered as practicing the target language which means the more the students practice communicating using the target language, the higher levels of communicative competence and achievement the students get (Bernales, 2016). 
Astuti (2011) states that the success of the teaching and learning process as well as the students' language ability and achievement are determined by the interaction that happened in the classroom. Chaudron (1998:10) quoting Allwright's point about the significance of interaction using L2 language during the process of teaching and learning: (1) the target language structure as well as its meaning can be explored only by communicating with each other; (2) communicating with each other provides the students chances to use the target language structure into their own speech; (3) the meaningfulness for students depends on the degree in which communication has been formed between the teacher and students. Based on that explanation, interaction using L2 language during the process of teaching and learning is important since it eases the students to promote and discover their communicative competence.

The classroom interaction can be encouraged through some methods. Those are: (1) improving question strategies, (2) attending to students' linguistic levels, (3) enforcing cooperative learning strategies, (4) developing a positive relationship between teacher and students, and (5) reducing classroom anxiety (Jia, 2013).

According to research conducted by Bonavetti (2015), it is considered as genuine communication only when interlocutor has eagerness and purpose of communication, and when it focuses on the content and absolutely without any control either by the teacher or the material. It is related to the main objective of Communicative Language Teaching (CLT) strategy which has to teach "communicative competence" or the speaking skill using the target language properly to achieve the communication goal. In short, the teaching and learning process which adopted the communicative approach shows an ideal language class where the predominant role is on the students, and also meaningful communication between each member is encouraged.

Despite the positive effects of genuine communication, when students are given a chance to speak, some students prefer to speak up while some students prefer to remain silent. There is a possibility that the students are afraid to speak or anxious about their speaking skill. As a teacher, it is essential to find out the reason why students remain silent during the process of teaching and learning. As cited in Nande (2017) there are linguistic and non-linguistic factors that may contribute to 
the students' willingness to communicate. Linguistic factors that may contribute are students' vocabulary mastery, grammar, and pronunciation. On the other hand, nonlinguistic factors that may contribute are students' motivation, anxiety, shyness, and many other factors depend on the students' personality.

MacIntyre et al. (1998) presented a Heuristic model of willingness to communicate in the second language which has six layers or categories. The six layers presented as representatives of two basic structures are: (a) layer I, II, and III as representatives of situation-specific that influence willingness to communicate at a certain time and (b) layer IV, V, and VI as representatives of stable and enduring influences on the process. See Figure 1 Heuristic Model of Variables Influencing WTC below.

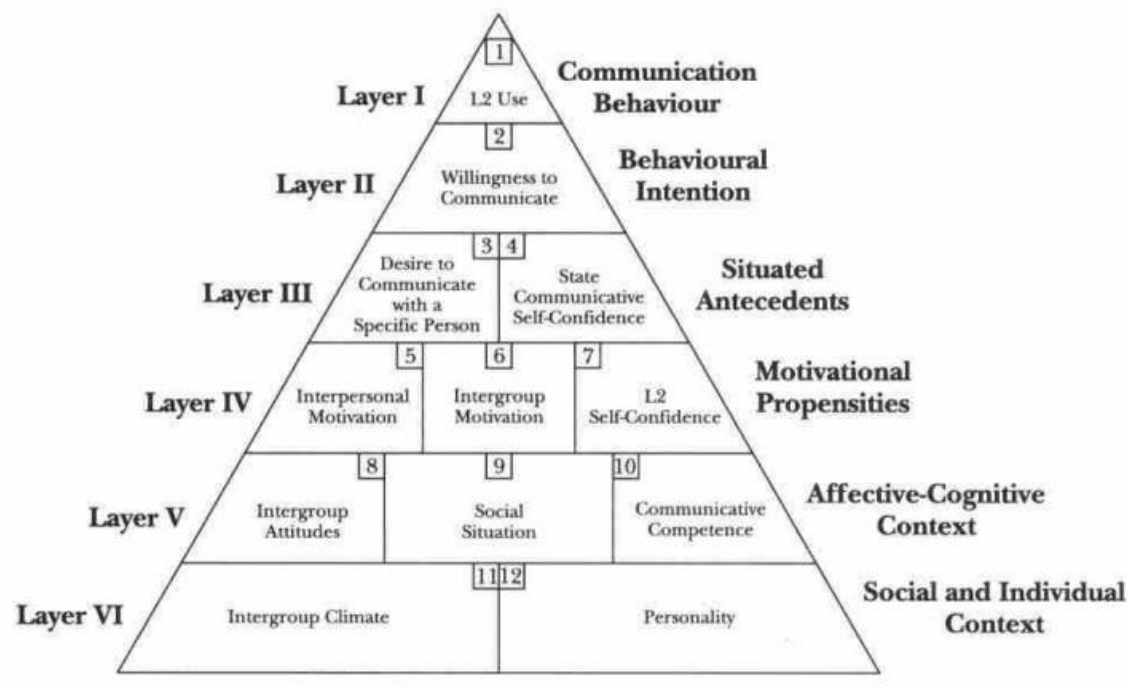

\section{Figure 1 Heuristic Model of Variables Influencing WTC}

Source: MacIntyre et al. (1998:547)

Due to various factors that contribute to students' willingness, it is essential to investigate the reason why some students remain silent during the process of teaching and learning. If the factors that contribute to the students' willingness to communicate have been found, the teachers can find suitable strategies that may help the students to actively participate in the classroom interaction.

Therefore, this study aims to investigate students' perceptions towards willingness to communicate using English in the classroom. Also, it aims to find 
further information about the factors that contribute to the students' willingness to communicate using English in the classroom.

\section{RESEARCH METHOD}

This study employs a quantitative approach, specifically a survey research design. Creswell (2012: 375) states that survey research designs are part of quantitative research where the researchers conduct a survey to a representative sample or the entire population of people to give a description of opinions, attitudes, characteristics, or behavior of the population. Therefore, a survey research design is suitable to investigate senior high school students' perception towards willingness to communicate using English and also the factors which contribute to their willingness to communicate using English in the classroom. At the end of this study, the result can be used for teachers to maximize the learning outcomes by creating a certain situation that makes the students willing to communicate using English.

Since survey research design can be done with a large group of population involving a lot of people, cluster random sampling is used in this study. The participants of this study are tenth and eleventh grade students at SMK Negeri 10 Malang. The total respondents of this study are 115 participants for questionnaires which are 55 participants from the tenth grader and 60 participants from eleventh grade students.

To obtain the data from the respondents, this study used online questionnaires using Google form and also online interview. The questionnaire was adapted from research by Elaine K. Horwitz, Michael B. Horwitz, and Joann Cope in 1986 about foreign language classroom anxiety. The questions were translated into Bahasa Indonesia to avoid any misunderstanding.

After the data from the questionnaire has been collected, some students were selected randomly to join the interview. The interview was also conducted to follow-up on the questionnaire responses. The interview was done after the students fill in the questionnaire so that the students are already familiar with the questions as well as the topic that was delivered during the interview. The data were then organized into tables along with the percentile and described in a narrative way. 


\section{DISCUSSIONS}

\section{Students' Perception towards Willingness to Communicate Using English}

There are three sub aspects about students' perception towards willingness to communicate using English that is being discussed which are (1) the importance of learning and using English; (2) the usefulness of communicating using English; and also (3) the students' willingness to communicate using English itself.

\section{The Importance of Learning and Using English in the Classroom}

The students' perception towards the importance of learning and using English in the classroom is generated from the questionnaire and interview response. Based on the questionnaire response, 110 students $(95.7 \%$ of the respondents) agree that learning English is important. Also, 86 students (74.8\% of the respondents) agree that communicate using English in the classroom is quite important. Similar to the data collected from the interview, all participants agree that communicating using English is important even though they have some difficulties when communicating using English such as pronouncing the words, using the verbs, and also constructing the sentence. See table 1 below.

Table 1 Result of Students' Perception about the Importance of Learning and Using English in Classroom

\begin{tabular}{|c|c|c|c|}
\hline Statement & Response & Frequency & Percentage \\
\hline \multirow{2}{*}{$\begin{array}{l}\text { I think learning English is } \\
\text { important }\end{array}$} & Positive & 110 & $95.7 \%$ \\
\hline & Negative & 5 & $4.3 \%$ \\
\hline \multirow{2}{*}{$\begin{array}{l}\text { I think communicate using English } \\
\text { in the classroom is important }\end{array}$} & Positive & 86 & $74.8 \%$ \\
\hline & Negative & 29 & $25.2 \%$ \\
\hline
\end{tabular}

Thus, the finding shows that students have a positive opinion about the importance of learning and using English. The findings are supported by the act of the Republic Indonesia No. 32 of 2013, article 70 about how English is included in the national exam for senior high school as well as vocational high school. Additionally, article 77I as well as Nunan (2003) and Nishanti (2018) also state that foreign languages, especially English, are important. English, after all, is considered as an international language. From those statements, we can infer that it is important 
for students to learn and master English, at least as a requirement to pass the national exam.

\section{The Usefulness of Communicating Using English}

Based on the questionnaire responses, $90.4 \%$ of the participants agree to a statement that communicating using English has so many advantages for students. It helps improve their speaking ability, enrich their vocabulary, and also boost their confidence. The findings from the questionnaire show that more than $50 \%$ of the students have a positive opinion about the aforementioned statements. Out of all of the respondents, 104 students agree that communicating using English helps them to understand English better and also it improves their speaking ability. Other than that, 99 students agree that communicating in English in classroom enriches their vocabularies and 82 students agree that communicating in English in classroom boosts their confidence. See table 2 below.

Table 2 Result of Students' Perception about the Usefulness of Communicating Using English in the Classroom

\begin{tabular}{|c|c|c|c|}
\hline Statement & Response & Frequency & Percentage \\
\hline Communicating using English & Positive & 104 & $90.4 \%$ \\
\hline $\begin{array}{l}\text { in the classroom help me } \\
\text { understand English better }\end{array}$ & Negative & 11 & $9.6 \%$ \\
\hline Communicating using English & Positive & 104 & $90.4 \%$ \\
\hline $\begin{array}{l}\text { in the classroom can improve } \\
\text { my speaking skill }\end{array}$ & Negative & 11 & $9.6 \%$ \\
\hline Communicating using English & Positive & 99 & $86.1 \%$ \\
\hline $\begin{array}{l}\text { in the classroom enrich my } \\
\text { vocabularies }\end{array}$ & Negative & 16 & $13.9 \%$ \\
\hline Communicating using English & Positive & 82 & $71.3 \%$ \\
\hline $\begin{array}{l}\text { in the classroom boost my } \\
\text { confidence }\end{array}$ & Negative & 33 & $28.7 \%$ \\
\hline
\end{tabular}

The findings of this study are in line with a research conducted by Swain (1995) stating that by communicating using the target language, students may recognize something between what they have in mind and what they actually can 
say. It will lead the students to acknowledge something they do not know about the language before. Communicating using English in the classroom will stimulate the students to recognize their linguistic problem and make them realize something they do not know about the target language.

\section{Students' Willingness to Communicate Using English in the Classroom}

The findings from the questionnaire and also the interview show that the students' willingness to communicate in English is quite low. Only 46 students (40\% of the respondents) are willing to answer questions raised by the teacher and 73 students $(63.5 \%$ of the respondents) answer a question only if the teacher asks them to. Other than that, only $8.7 \%$ of the respondents (10 students) communicate using English during group discussion and $6.1 \%$ of the respondents (7 students) deliver their opinion using English. Even if the students actually wanted to communicate using English, yet they do not really communicate using English when they are given opportunities, it does not imply that the students actually have a willingness to communicate using English. See table 3 below.

Table 3 Result of Students' Willingness to Communicate Using English in the Classroom

\begin{tabular}{llll}
\hline Statement & Response & Frequency & Percentage \\
\hline I am willing to answer a & Positive & 46 & $40 \%$ \\
\cline { 2 - 4 } question from the teacher & Negative & 69 & $60 \%$ \\
\hline I will answer a question if my & Positive & 73 & $63.5 \%$ \\
\cline { 2 - 4 } teacher asked me to & Negative & 42 & $36.5 \%$ \\
\hline I communicate using English & Positive & 10 & $8.7 \%$ \\
\cline { 2 - 4 } during group discussion & Negative & 105 & $91.3 \%$ \\
\hline I deliver my opinion using & Positive & 7 & $6.1 \%$ \\
\cline { 2 - 4 } English in the classroom & Negative & 108 & $93.9 \%$ \\
\hline
\end{tabular}

From the data collected from the interview, most of the students are rarely and almost never communicate using English. Some reasons involve their teachers often not using English during the process of teaching and learning or the students themselves do not know how to communicate using English fluently. Some of the 
respondents state that they only communicate using English when their teachers ask them to or when their teachers give them assignments that require them to communicate using English. Some of them also state that they prefer to communicate using Bahasa Indonesia or even Bahasa Daerah because they are not used to communicate using English.

McCroskey (1977) mentions that people who have a great level of communication apprehension will most likely avoid communicating with others so that they will not face his/her fear. As cited in a research by McCroskey (1977), communication apprehension is a language learners' degree of fear or anxiety related to either with real or expected communication with other individuals. During the process of teaching and learning, students might actually want to communicate using English, since students' proficiency is not really good and also they are not used to use English in the classroom, they might make mistakes when communicating using English. Therefore, it can be one of the reasons why the students unwilling to communicate using English and prefer to use Bahasa Indonesia or even Bahasa Daerah in which they are already familiar with to avoid getting negative feedback from other people.

In line with these findings, Freiermuth and Jarrel (2006) state that ineffective interaction as well as learners' performance caused by a lack of willingness to communicate. A language class following the communicative approach, students' willingness to communicate using English is important as it is expected to facilitate the students to practice authentic language use.

\section{Linguistic Factors that Contribute to Students' Willingness to Communicate Using English in the Classroom}

Linguistic factors that may contribute to students' language acquisition and willingness to communicate are vocabulary, grammar, and pronunciation.

\section{Vocabulary}

The first linguistic factor that contributes to students' willingness to communicate using English is vocabulary. The findings from the questionnaire response show that 86 students $(74.8 \%$ of the respondents) have difficulties in understanding English words. Students' lack of vocabulary affects the students' 
willingness to communicate because learners are unable to communicate with other people and expressing their ideas using English. Thus, it led the students for being silent during the process of teaching and learning. See table 4 below.

Table 4 Result of Students' Questionnaire about Vocabulary

\begin{tabular}{llll}
\hline Statement & Response & Frequency & Percentage \\
\hline I do not really understand & Positive & 86 & $74.8 \%$ \\
\cline { 2 - 4 } English words & Negative & 29 & $25.2 \%$ \\
\hline It is difficult for me to find the & Positive & 89 & $77.3 \%$ \\
\cline { 2 - 4 } most suitable English word & Negative & 26 & $22.7 \%$ \\
\hline
\end{tabular}

This finding is in line with Fadilah (2018) that the lack of vocabulary, grammar, and pronunciation causes the students to get stuck when they are trying to communicate using English. If students do not have a wide vocabulary it may restrict them from communicating in English. In the interview, one of the respondents mentions that it's difficult to learn English when she does not understand the meaning of something and also when the sentence is long. However, once she knows the meaning, it becomes less difficult. Other respondents also state that using an online dictionary can help them understand English words better.

Furthermore, 89 students ( $77.3 \%$ of the respondents) agree that they have difficulties finding the most suitable words. This finding is supported by a research conducted by Fadilah (2018) that the factors which restrict the students to participate in a communication are the lack of grammatical competence, vocabulary, and also pronunciation. Another supporting view is the research by Bernales (2016) which mentions that students' unwillingness to transfer what they have in mind into utterance could be an indication that the students are struggling with the complex grammar and vocabulary especially when the students have to respond directly. Students may actually know the words or the answer of a certain question in mind, however, they may not be able to deliver their thought using English well due to their lack of vocabulary. 


\section{Grammar}

The second linguistic factor that contributes to students' willingness to communicate using English is grammar. The finding from the questionnaire shows that 88 students ( $76.5 \%$ of the respondents) have difficulties constructing sentences. Also, during the interview, some of the respondents mention that their difficulty in communicating in English is related to sentence construction. Students have to understand the English language structure so that they can communicate using English well. Also, they have to understand the structure's rules and also how words change their form in a certain sentence. See table 5 below.

Table 5 Result of Students' Questionnaire about Grammar

\begin{tabular}{llll}
\hline Statement & Response & Frequency & Percentage \\
\hline I do not really understand how & Positive & 88 & $76.5 \%$ \\
\cline { 2 - 4 } to construct sentences & Negative & 27 & $23.5 \%$ \\
\hline I am afraid of constructing & Positive & 79 & $68.7 \%$ \\
\cline { 2 - 4 } wrong sentences & Negative & 36 & $31.3 \%$ \\
\hline
\end{tabular}

A research conducted by Horwitz et al. (1986) supports the finding that students commonly have knowledge about some grammar points but there might be a chance that they forget that certain grammar points during a test or oral practice when many grammar points must be memorized and integrated. From Horwitz's explanation, it can be inferred that some students actually know how to construct grammatically correct sentences. However, they may forget the grammar structure when they have to communicate using English without proper preparation.

Another finding from the questionnaire shows that 79 students are afraid of constructing wrong sentences. In line with a research conducted by Riasati (2012), EFL students are concerned too much for constructing grammatically correct sentences of their speech affecting their fluency in which it is sometimes neglected. When communicating, speakers are usually over concerned with the correctness of their utterances and if they are not really sure about this, they avoid communicating. One of the reasons why the students are worried if they make any mistakes when communicating using English maybe because they are paying too much attention 
to what they are going to say and unable to construct their ideas in a grammatically correct way.

This finding is also in line with Krashen's research (1981) which expresses that in communication, speakers usually do not have enough time to think and use conscious grammar rules. It is very possible for students to make grammatical mistakes when they are communicating using English without any preparation. However, most of them are afraid of it and prefer to avoid communicating in English.

\section{Pronunciation}

The result of the questionnaire shows that $60 \%$ of the respondents stated that they have difficulties in pronouncing English words. Meanwhile, $40 \%$ of the respondents do not really have difficulties in pronouncing English word.

Other than that, $57.4 \%$ of the respondents feel embarrassed if they mispronounce the English word. In opposite, the other $42.6 \%$ of the respondents do not have the same opinion. See table 6 below.

Table 6 Result of Students' Questionnaire about Pronunciation

\begin{tabular}{llll}
\hline Statement & Response & Frequency & Percentage \\
\hline I have difficulties pronouncing & Positive & 69 & $60 \%$ \\
\cline { 2 - 4 } English words & Negative & 46 & $40 \%$ \\
\hline I feel embarrassed if I & Positive & 66 & $57.4 \%$ \\
\cline { 2 - 4 } mispronounce English words & Negative & 49 & $42.6 \%$ \\
\hline
\end{tabular}

Based on the findings from the questionnaire, 69 students $(60 \%$ of the respondents) are found to have difficulties in pronouncing English words. Horwitz et al. (1986) report that language learners complain of having problems discriminating the sounds and structures of a target language. In the interview, four out of ten respondents are not used to communicate using English in class, they actually prefer to use Bahasa Indonesia and Bahasa Daerah which are their mother tongue. Since English and their mother tongue have different ways of pronouncing words and they also have little exposure to English communication, they find pronouncing English words quite difficult. 
Besides, the findings from the questionnaire show that 66 students $(57.4 \%$ of the respondents) feel embarrassed when they mispronounce English words. A research conducted by Horwitz et al. (1986) supports the finding of this study on how many students believe something in a foreign language should not be said until they can say it correctly and guessing an unknown foreign language word is not okay. When a student mispronounces a certain English word in front of many people, there will be a chance for that certain student to be laughed by the audience and it can be pretty embarrassment. One of the respondents also states during the interview one respondent also comments how some words can have similar pronunciation and it makes him confused about how to pronounce them correctly.

\section{Non-linguistic Factors that Contribute to Students' Willingness to}

\section{Communicate Using English in the Classroom}

Non-linguistic factors that contribute to students' willingness to communicate using English are interlocutor, motivation, anxiety, social situation, and topic interest.

\section{Interlocutor}

The first non-linguistic factor that contributes to students' willingness to communicate using English is the interlocutor. Based on the result of the questionnaire only 10 students ( $8.7 \%$ of the respondents) communicate using English with their teachers and only 5 students (4.4\% of the respondents) communicate using English with their friends (See table 3.7 below).

Riasati (2012) says that motivation from a partner is needed by language learners and most learners do not want to be the only speaker all the time and instead they prefer to exchange ideas. Some students may feel more comfortable communicating with their friends as they have a similar level of communicative competence.

Some respondents in the interview also mention that their teachers would encourage students when they do not want to speak during the teaching and learning process. Nande (2017) agrees that learners would not feel reluctant to speak if they have a good teacher who is kind and could teach them patiently. One of the respondents in the interview stated that his teacher is the main factor that influences 
his willingness to communicate using English because when the students do not understand what the teacher is saying, the teacher will translate it into Bahasa Indonesia which helps the students to improve their vocabulary.

MacIntyre et al. (1998) mention that most of the time we have a conversation with people around us with a certain intention: because we need their guidance, their cooperation, or their services. In the interview, most of the respondents state that they only communicate using English when their teachers asked them to. It can be inferred that students would only use English with their teachers as they need their teachers' guidance during the process of teaching and learning.

Besides, the findings from the questionnaire also show that 29 students (25.2\% of the respondents) feel confident communicating using English with their teachers and 27 students $(23.5 \%$ of the respondents) feel more confident when communicating using English with their friends. Supported by MacIntyre (1998) that friendship may be formed through communication, but most of the time communication in the classroom will be guided by the teacher. A teacher's role is essential in students' willingness to communicate using English as the teacher is the one who will lead the teaching and learning process. In line with a research conducted by Nande (2017) states that in the class, the teacher should ensure that the students feel as little anxiety as possible in the class activities and act as a facilitator who steps back and encourages students to be able to speak naturally.

Table 7 Result of Students' Questionnaire about Interlocutor

\begin{tabular}{lllll}
\hline \multicolumn{2}{l}{ Statement } & Response & Frequency & Percentage \\
\hline I communicate using English & Positive & 10 & $8.7 \%$ \\
\cline { 2 - 4 } $\begin{array}{l}\text { with the teacher } \\
\text { I feel confident to }\end{array}$ & Negative & 65 & $91.3 \%$ \\
\cline { 2 - 4 } $\begin{array}{l}\text { communicate using English } \\
\text { with the teacher }\end{array}$ & Negative & 86 & $25.2 \%$ \\
\hline I feel embarrassed if my & & & $74.8 \%$ \\
teacher correct my mistake & Nogitive & 39 & $33.9 \%$ \\
\hline & Posative & 76 & $66.1 \%$ \\
\hline
\end{tabular}




\begin{tabular}{|c|c|c|c|}
\hline $\begin{array}{l}\text { I communicate using English } \\
\text { with my friends in the } \\
\text { classroom }\end{array}$ & Negative & 110 & $95.6 \%$ \\
\hline I feel more confidence & Positive & 27 & $23.5 \%$ \\
\hline $\begin{array}{l}\text { communicating using English } \\
\text { in the classroom with my } \\
\text { friends }\end{array}$ & Negative & 88 & $76.5 \%$ \\
\hline I feel embarrassed if my & Positive & 36 & $31.3 \%$ \\
\hline friends correct my mistakes & Negative & 79 & $68.7 \%$ \\
\hline
\end{tabular}

\section{Motivation}

The result of the questionnaire shows that $68.7 \%$ of the respondents agree to a statement that communicating using English is quite difficult. However, there is still $31.3 \%$ of the respondents who think otherwise. In addition, similar to the previous result, $68.7 \%$ of the respondents state that they do not feel motivated to use English in the classroom. Nevertheless $31.3 \%$ of the respondents have different opinion. See table 8 below.

Table 8 Result of Students' Questionnaire about Motivation

\begin{tabular}{|c|c|c|c|}
\hline Statement & Response & Frequency & Percentage \\
\hline I think communicating using & Positive & 79 & $68.7 \%$ \\
\hline English is difficult & Negative & 36 & $31.3 \%$ \\
\hline I lack of motivation to & Positive & 79 & $68.7 \%$ \\
\hline $\begin{array}{l}\text { communicate using English in } \\
\text { the classroom }\end{array}$ & Negative & 36 & $31.3 \%$ \\
\hline
\end{tabular}

During the interview, most respondents state that their difficulty is related to vocabulary, grammar, and pronunciation. Just like the previous finding, 79 students agree that they do not have the motivation to communicate in English. This finding is supported by McCroskey and Richmond (1991) who state that students who have negative attitude towards school are having a lack of motivation and they will likely put less effort to communicate. MacIntyre (1998) also states that satisfaction in learning and communicating using the $\mathrm{L} 2$ will urge each learner to put more intense 
efforts to the process of learning the target language. It happens when there are positive experiences in the process of learning the language and in other contexts where the learners are given an opportunity to communicate using the language (e.g., with friends). It can be inferred that students' will have no willingness to communicate using English if the classroom situation is not enjoyable for them or if the person the student talks to (teacher or friends) does not motivate them to communicate using English.

\section{Anxiety}

The third non-linguistic factor that contributes to students' willingness to communicate using English is anxiety. The data obtained from the questionnaire show that 73 students ( $63.5 \%$ of the respondents) are afraid of making mistakes while communicating in English. Based on the data obtained from the interview, nine out of ten respondents stated that they have experienced the feeling of nervousness, embarrassment, and fear. There are four out of ten respondents who state that they are afraid of making mistakes or mispronounce the words. Four out of ten respondents also mentioned that they are afraid of being laughed when they make a mistake while communicating in English. MacIntyre (2007) also supports the view that students who are unwilling to communicate mostly have an anxiety problem about communicating. Students who have high anxiety levels most of the time will likely avoid communicating so that they will not be judged by other people.

Another finding from the questionnaire shows that 64 students $(55.7 \%$ of the respondents) is afraid of being laughed if they make mistakes while communicating using English. In line with a research conducted by Horwitz et al. (1986), generally, both teachers and students realize that the major factor to conquer in the process of learning target language is anxiety. If students avoid speaking because they feel afraid, nervous, or embarrassed, it will affect their performance.

Besides, from the data collected from the questionnaire, 92 students $(80 \%$ of the respondents) (See table 9 below) experience panic when they are required to communicate using English without enough preparation. This finding is supported by Horwitz et al. (1986) which mention students mostly experienced apprehension, 
worry, and even dread. Learners will experience difficulty concentrating, become forgetful, sweating, and palpitation when they are asked to speak without enough preparation. From those findings, we can infer that students feel panic and have difficulty in concentrating, even become forgetful when they are asked to communicate using English without enough time to think.

Table 9 Result of Students' Questionnaire about Anxiety

\begin{tabular}{llll}
\hline Statement & Response & Frequency & Percentage \\
\hline I am afraid of making mistake & Positive & 73 & $63.5 \%$ \\
\cline { 2 - 4 } when communicating using & Negative & 42 & $36.5 \%$ \\
English & & 64 & $55.7 \%$ \\
\hline I am afraid of being laughed if & Positive & $64.3 \%$ \\
\cline { 2 - 4 } I make a mistake when & Negative & 51 & \\
communicating using English & & & $80 \%$ \\
\hline I panic if I have to & Positive & 92 & $20 \%$ \\
\cline { 2 - 4 } communicate using English & Negative & 23 & \\
without preparation & & & \\
\hline
\end{tabular}

\section{Social Situation}

The data collected from the questionnaire shows that $86.9 \%$ of the respondents agree that they do not feel confident when they are required to communicate using English in front of many people. However, $13.1 \%$ of the respondents disagree with the statement. See table 10 below.

Table 10 Result of Students' Questionnaire about Social Situation

\begin{tabular}{llll}
\hline Statement & Response & Frequency & Percentage \\
\hline I am lack of confidence when I & Positive & 100 & $86.9 \%$ \\
\cline { 2 - 4 } have to communicate using & Negative & 15 & $13.1 \%$ \\
English in front of many & & & \\
people & & & \\
\hline
\end{tabular}

From the result of the questionnaire, to communicate using English in front of many people affect the students' willingness. According to the interview response, four out of ten respondents choose situation as the most contributing 
factor to their willingness to communicate using English. In line with a research conducted by Horwitz et al. (1986), when learners' performance is continuously monitored and they almost have no control over the situation, learners who are having difficulties communicating in a group will likely have greater difficulty speaking in a larger language class.

\section{Topic of Interest}

According to the data gathered through the questionnaire, $54.7 \%$ of the respondents agreed that they will be willing to communicate using English if the topic of discussion is interesting. Meanwhile, the rest $45.3 \%$ of the respondents disagree with the statement.

Similar to the previous statement, $58.2 \%$ of the respondents agree that they are willing to communicate using English if they like the topic of discussion. However, there are still $41.8 \%$ of the respondents who do not have the same opinion about the statement as shown in table 11 below. MacIntyre et al. (1998) indicate topical expertise and familiarity will significantly affect the ease of language use. On the other hand, lacking of expertise and familiarity with the topic will affect even a generally great speaker. Teachers can improve students' communication by proposing appropriate topics. Fojkar (2005) also mentions that students can say so much more when they are interested in the topic rather than something they do not familiar with.

Table 11 Result of Students' Questionnaire about Topic of Interest

\begin{tabular}{llll}
\hline Statement & Response & Frequency & Percentage \\
\hline I am willing to communicate & Positive & 63 & $54.7 \%$ \\
\cline { 2 - 4 } $\begin{array}{l}\text { using English if the topic } \\
\text { discussed is interesting }\end{array}$ & Negative & 52 & $45.3 \%$ \\
\hline I am willing to communicate & Positive & 57 & $58.2 \%$ \\
\cline { 2 - 4 } $\begin{array}{l}\text { using English if I like the topic } \\
\text { discussed }\end{array}$ & Negative & 48 & $41.8 \%$ \\
\hline
\end{tabular}

When the students are given a topic which they do not know, it may restrict the students to participate in the classroom discussion because they do not know 
what they are going to say. A research conducted by Riasati (2012) supports the findings of this study, stating that learners believe that topics significantly influence the degree of their willingness to communicate. When they already have enough information or knowledge about a certain topic, it will increase the students' willingness to communicate about it.

\section{CONCLUSION}

The findings of this study shows that some variables presented in the heuristic model such as communicative competence, desire to communicate with a certain person, motivation, anxiety, social situation, as well as topic of discussion do affect tenth and eleventh grade students at SMK Negeri 10 Malang's willingness to communicate in English.

Furthermore, three linguistic factors contribute to students' willingness and unwillingness to communicate using English. Those linguistic factors; vocabulary, grammar, and pronunciation do affect vocational high school students' willingness to communicate using English. Based on the findings, vocabulary and grammar affect the students' willingness to communicate using English more than pronunciation even though they state that pronouncing English words is difficult, also they are afraid of making mistakes when pronouncing the word.

Also, five non-linguistic factors contribute to the students' willingness to communicate using English. Those non-linguistic factors are interlocutor, motivation, anxiety, social situation, and topic interest. From those five nonlinguistic factors, anxiety and social situation do contribute to the students' willingness to communicate using English more than the other non-linguistic factors.

Based on the findings and discussion in the previous chapter, it is concluded that tenth and eleventh grade students at SMK Negeri 10 Malang have a positive opinion towards willingness to communicate using English in the classroom. They stated that learning and communicating using English is essential and beneficial. However, their willingness to communicate using English itself is quite low and it is quite a serious problem. 


\section{REFERENCES}

Astuti, M. 2011. An Analysis of Classroom Interaction in the English Teaching and Learning Process of the Bilingual Class in the First Grade of SMPN 1 Prambanan. Skripsi tidak diterbitkan. Yogyakarta: Universitas Negeri Yogyakarta

Bernales, C. 2016. Towards a Comprehensive Concept of Willingness to Communicate: Learners' Predicted and Self-reported Participation in the Foreign Language Classroom. System, 56, 1-12. Dari https://www.sciencedirect.com/science/article/abs/pii/S0346251X150017 12.

Bonavetti, M. C. 2015. Oral Interaction in the Classroom: An Up-close View at the English as a Foreign Language Teaching Program at Universidad Adventista del Plata. Enfoques XXVII 1, 51-57. Dari https://www.researchgate.net/publication/295010287_Oral_interaction_i $\underline{\text { n the classroom_an_up- }}$ close_view_at_the_English_as_a_Foreign_Language_Teaching_Program at_Universidad_Adventista_del_Plata

Brown, D. H. 2001. Teaching by Principles: An Interactive Approach to Language Pedagogy. New York: Pearson Education - Longman

Creswell, J. W. 2012. Educational Research: Planning, Conducting, and Evaluating Quantitative and Qualitative Research. Boston: Pearson.

Fadilah, E. 2018. Willingness to Communicate from Indonesian Learners' Perspective: A Dynamic Complex System Theory. Journal of ELT Research, 3(2), 168-185. Dari https://www.researchgate.net/publication/327577707_Willingness_to_Co mmunicate_from_Indonesian_Learners'_Perspective.

Fojkar, M.D. 2005. Classroom Interaction and Communication Strategies in Learning English as a Foreign Language. ELOPE: English Language Overseas Perspective and Enquiries, 1(1-2), 127-139. Dari https://www.researchgate.net/publication/279999107_Classroom_Interacti on_and_Communication_Strategies_in_Learning_English_as_a_Foreign_ Language.

Freiermuth, M., Jarrel, D. 2006. Willingness to communicate: Can online chat help? International Journal of Applied Linguistics, 16(2): 189-212. Dari https://www.semanticscholar.org/paper/Willingness-to-communicate\%3Acan-online-chat-help1-FreiermuthJarrell/00ac17d98195095791ff218b403f0ec41a3a95bb

Horwitz, E.K., Horwitz, M. B., Cope J. 1986. Foreign Language Classroom Anxiety. The Modern Language Journal, 70 (2), 125-132. Dari https://www.academia.edu/3131037/Foreign_language_classroom_anxiety 
Jia, X. 2013. The Application of Classroom Interaction in English Lesson. Presented on International Conference on Education Technology and Information System, China, $22^{\text {nd }}$ of June.

Krashen, S. D. 1981. Second Language Acquisition and Second Language Learning. Oxford: Pergamon Press.

MacIntyre, P., Clément, R., \& Noels, K.A. 1998. Conceptualizing Willingness to Communicate in a L2: A Situational Model of L2 Confidence and Affiliation. Modern Language Journal, 82(4), 545-562. Dari https://www.researchgate.net/publication/216308808_Conceptualizing_Wi $\underline{\text { llingness_to_Communicate_in_a_L2_A_Situational_Model_of_L2_Confi }}$ dence_and_Affiliation.

MacIntyre, P.D. 2007. Willingness to Communicate in the Second Language: Understanding the Decision to Speak as a Volitional Process. The Modern Language Journal, $91 \quad$ (4), 564-576. Dari https://www.academia.edu/4056476/Willingness_to_Communicate_in_th e_Second_Language_Understanding the Decision_to_Speak_as_a_Voli tional_Process

McCroskey, J. C. 1977. Oral Communication Apprehension: A Summary of Recent Theory and Research. Human Communication Research, 4(1), 78-96. Dari https://www.researchgate.net/publication/229753314_Oral_communicati on_A_summary_of_recent_theory_and_research

McCroskey, J. C., \& Richmond, V. P. 1991. Quiet Children and Classroom Teacher. ERIC Clearinghouse on Reading and Communication Skills:; Indiana University

Nande, M. 2017. Factors Affecting Students' Reluctance to Speak: A Case Study of an Interest-based Class in SMAN 1 Tumpang. Skripsi tidak diterbitkan. Malang: FS UM.

Nunan, D. 2003. The Impact of English as a Global Language on Educational Policies and Practices in the Asia-Pacific Region. TESOL Quarterly, 37(4). Dari https://www.semanticscholar.org/paper/The-Impact-ofEnglish-as-a-Global-Language-on-and-

Nunan/911be36b6555023bc8f8e4508cc34f54d6de96b8

Pemerintah Republik Indonesia. 2013. Peraturan Pemerintah Republik Indonesia No. 32 Tahun 2013 tentang Standar Nasional Pendidikan

Riasati, M.J. 2012. EFL Learners' perception of Factors Willingness to Speak English in Language Classroom: A Qualitative Study. World Applied Sciences Journal, 17 (10), 1287-1297. Dari https://pdfs.semanticscholar.org/2561/011fc69693a71ca5000d6a3bd3a6f e97be85.pdf.

Swain, M. 1995. Three Functions of Output in Second Language Learning. In Principles and Practice in Applied Linguistics. Oxford: Oxford University Press. 125-144 